\title{
Glossostyles perspicua gen. et sp. nov. and other fungivorous Cecidomyiidae (Diptera) new to the Czech and Slovak Republics
}

\author{
Tomáš SIKORA ${ }^{1, *}$, Mathias JASCHHOF ${ }^{2}$ \& Jan ŠEVČÍK ${ }^{3}$ \\ ${ }^{1,3}$ Department of Biology and Ecology, Faculty of Science, University of Ostrava, \\ Chittussiho 10, CZ-710 00 Ostrava, Czech Republic. \\ ${ }^{2}$ Station Linné, Ölands Skogsby 161, SE-38693 Färjestaden, Sweden. \\ ${ }^{3}$ Silesian Museum, Nádražní okruh 31, CZ-746 01 Opava, Czech Republic. \\ *Corresponding author: sikothomas@gmail.com \\ ${ }^{2}$ E-mail: mjaschhof@yahoo.de \\ ${ }^{3}$ E-mail: sevcikjan@hotmail.com \\ ${ }^{1}$ urn:Isid:zoobank.org:author:C60CF76B-BDC5-45F2-82B8-2B6FB37B195F \\ ${ }^{2}$ urn:1sid:zoobank.org:author:8B4B11B4-7C33-41AC-A042-AA9903CDC4B1 \\ ${ }^{3}$ urn:lsid:zoobank.org:author:639373EF-6D46-40F6-929B-0C861C6C39F6
}

\begin{abstract}
Fungivorous gall midges of the subfamilies Lestremiinae, Micromyinae, Winnertziinae and Porricondylinae were largely neglected in previous inventories of the Diptera faunas of the Czech and Slovak Republics. A taxonomic-faunistic study focusing on these subfamilies identified a total of 80 species, of which 49 are new records for the Czech Republic and 33 are new records for Slovakia. Species that have never before been found in central Europe are Aprionus dalarnensis Mamaev, 1998, A. oligodactylus Jaschhof, 2009, A. pigmentalis Mamaev, 1998, Asynapta inflata Spungis, 1988, Camptomyia gigantea Spungis, 1989, Cassidoides fulviventris (Mamaev, 1964), Claspettomyia hamata (Felt, 1907), Dendrepidosis longipennis (Spungis, 1981), Dicerura dispersa Jaschhof, 2013, Divellepidosis lutescens (Spungis, 1981), D. pallescens (Panelius, 1965), D. vulgata Jaschhof, 2013, Ekmanomyia svecica Jaschhof, 2013, Holoneurus ciliatus Kieffer, 1896, Monepidosis pectinatoides Jaschhof, 2013, Neocolpodia gukasiani (Mamaev, 1990), Neurolyga acuminata Jaschhof, 2009, Neurolyga interrupta Jaschhof, 2009, Parepidosis planistylata Jaschhof, 2013, Peromyia bidentata Berest, 1988, Porricondyla errabunda Mamaev, 2001, P. microgona Jaschhof, 2013, P. tetraschistica Mamaev, 1988, Schistoneurus irregularis Mamaev, 1964, Spungisomyia fenestrata Jaschhof, 2013, S. media (Spungis, 1981), Tetraneuromyia lamellata Spungis, 1987, T. lenticularis (Spungis, 1987), and Winnertzia parvispina Jaschhof, 2013. A new genus including a single new species of Porricondylini is described and named Glossostyles perspicua Jaschhof \& Sikora gen. et sp. nov. on the basis of specimens collected in the Czech Republic and Sweden. Adult morphology suggests that Glossostyles gen. nov. is a close relative of Claspettomyia Grover, 1964.
\end{abstract}

Keywords. Palaearctic region, central Europe, new genus, new species, new faunistic records. 
Sikora T., Jaschhof M. \& Ševčík J. 2017. Glossostyles perspicua gen. et sp. nov. and other fungivorous Cecidomyiidae (Diptera) new to the Czech and Slovak Republics. European Journal of Taxonomy 303: 1-29. https://doi.org/10.5852/ejt.2017.303

\section{Introduction}

Gall midges, Cecidomyiidae, are a large family of small-sized, mostly short-lived dipterans that belong to the infraorder Bibionomorpha (Wiegmann et al. 2011; Ševčík et al. 2014) and, most probably, to the superfamily Sciaroidea (Ševčík et al. 2016). The family is best known for its herbivorous species (subfamily Cecidomyiinae), which account for about $4 / 5$ of the described biodiversity, while the five basal subfamilies (Catotrichinae, Lestremiinae, Micromyinae, Winnertziinae, Porricondylinae) contain solely fungivores, as far as the biology is known (Gagné \& Jaschhof 2014). Taxonomic research on the fungivorous subfamilies has intensified in recent years, leading to a reclassification of the entire family and improving the tools for the identification of species, especially in Europe (Jaschhof 1998; Jaschhof \& Jaschhof 2009, 2013). In the Czech and Slovak Republics (former Czechoslovakia) the study of gall midges is firmly established through the dedicated work of Marcela Skuhravá and Václav Skuhravý (see Bílý 2015), but was previously focused largely on Cecidomyiinae (e.g., Skuhravá 1991, 1994). This circumstance is not unusual and corresponds to the common practice of splitting responsibilities between workers on herbivorous gall midges, on the one hand, and fungivorous gall midges, on the other hand.

A research group established at the University of Ostrava to study mainly Bibionomorpha systematics, biodiversity and biology has recently expanded its research interest onto Cecidomyiidae, including the fungivorous subfamilies (Mantič et al. 2015). Another outcome from the faunistic-taxonomic surveys conducted by that group, which includes two of the present authors, is presented here, this time dedicated wholly to fungivorous gall midges. Considering that former efforts to inventory Czech and Slovak Diptera largely neglected these inconspicuous midges, it does not come as a surprise that the present study unveiled a number of new species records for either or both of the two countries. Other taxa were identified to be even new to science, including Glossostyles perspicua gen. et sp. nov., a new member of the tribe Porricondylini described in this paper.

\section{Material and methods}

Specimens for this study, mostly male adults, were collected in 1999-2015 by sweepnet (SW) and Malaise traps (MT) in a number of different localities in the Czech Republic (CZ) and Slovakia (SK). The range of habitats covered by these collecting efforts included natural woodland, peat-bogs, meadows, steppes and heathlands, with many of the collecting sites located in areas benefitting from some kind of conservation status, a fact accounting for the generally high habitat quality (Figs 1-2). Most of the specimens studied here were collected in the frame of several large-scale inventory projects organized by the Czech dipterists Miroslav Barták, Štěpán Kubík, Jindřich Roháček, and Jan Ševčík. For descriptions of the localities and collecting methods used in those projects, see Barták \& Kubík (2005), Kubík (2001), Roháček \& Ševčík (2009) and Ševčík \& Kurina (2011).

No attempt has been made at this stage to verify identifications by studying the respective voucher specimens of the Czech and Slovak species referred to in the literature. A series of both males and females of the newly described species were collected during an insect inventory in Tyresta National Park, Sweden, and received on loan from the Naturhistoriska Riksmuseet in Stockholm (NHRS). Specimens studied here were mounted on microscope slides according to the method described by Jaschhof \& Jaschhof (2009), with Hoyer's medium used instead of Canada balsam in a part of the material. Types of the new species are deposited in the National Museum in Prague (NMPC), other specimens in the 
SIKORA T. et al., Fungivorous Cecidomyiidae in the Czech and Slovak Republics
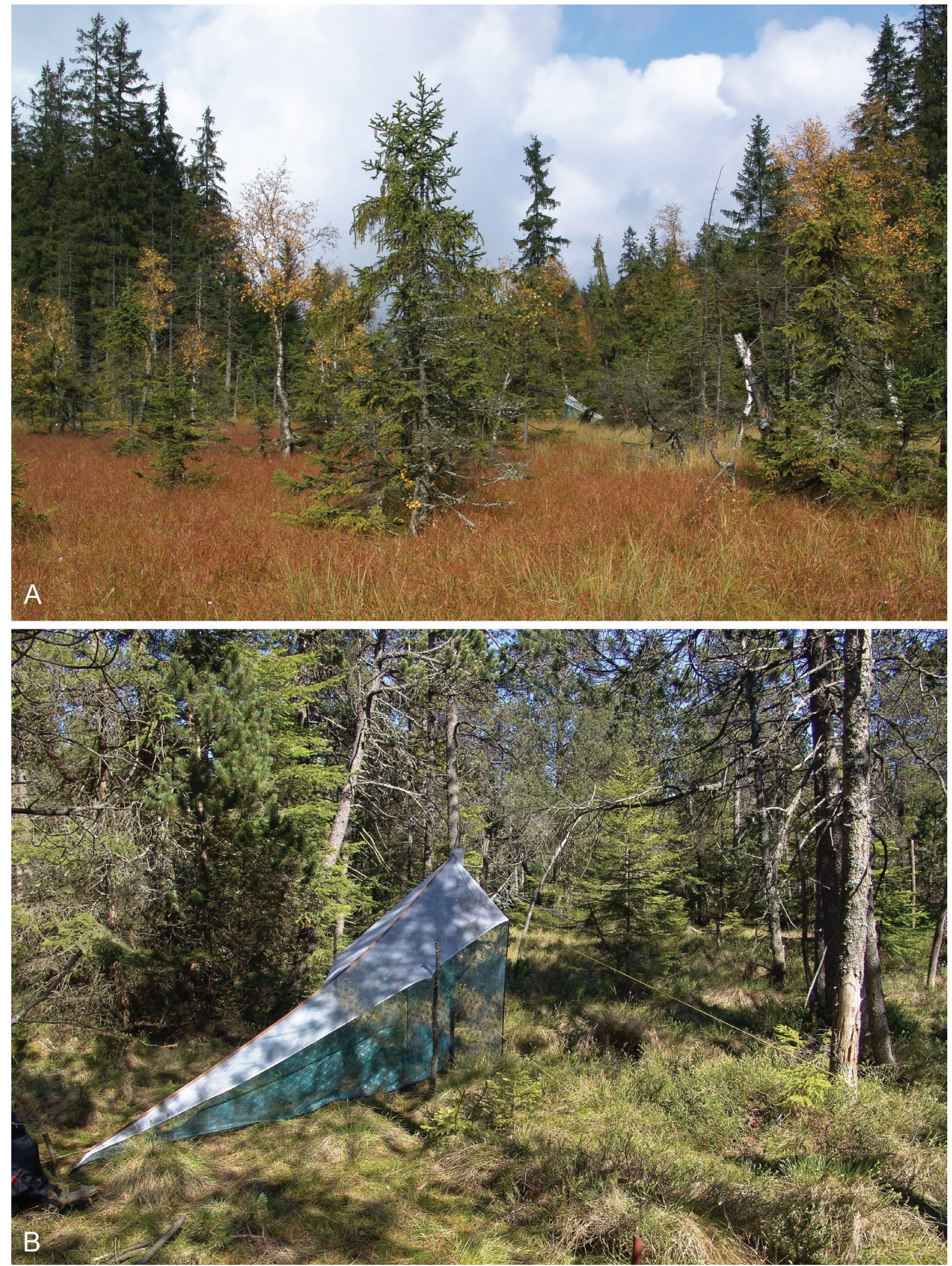

Fig. 1. Sampling localities. A. Rejvíz peat-bog (Czech Republic) with a Malaise trap used in 2004. A well preserved postglacial peat-bog with Pinus rotundata growth. B. Rejvíz peat-bog with the Malaise trap used in 2005. Photos by J. Ševčík. 

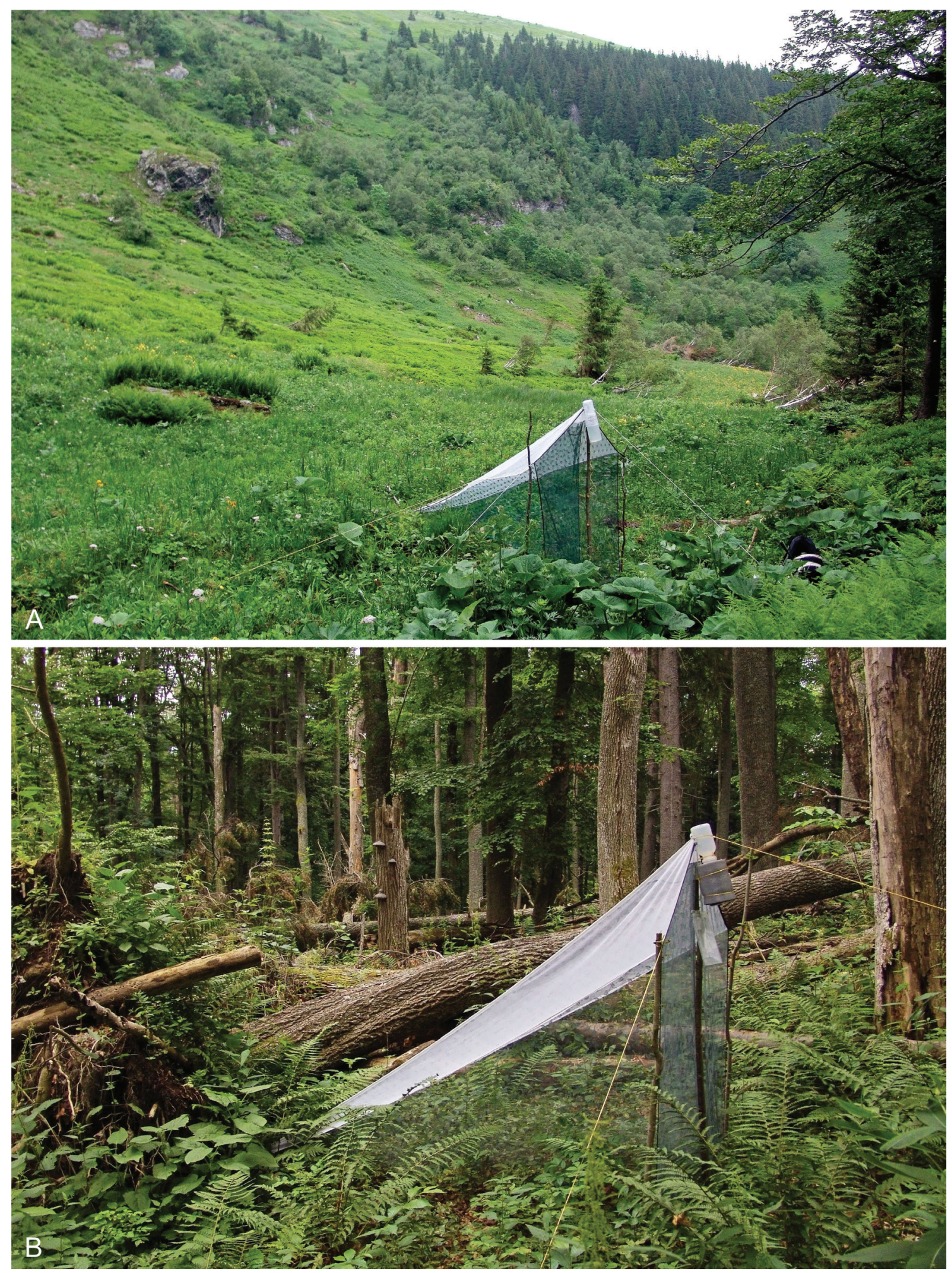

Fig. 2. Sampling localities. A. Velká Kotlina Glacial Cirque (Czech Republic) with a Malaise trap used in 2006. Frequent avalanches are the main cause of the unique subalpine biodiversity of this locality (e.g., more than 350 species of vascular plants have been recorded from there) B. Hrončecký grún̆ Reserve in Pol'ana Mts (Slovak Republic) with a Malaise trap used in 2005. This is a virgin forest mainly composed of fir and beech intermixed with ash, spruce and sycamore maple and with an enormous and unique diversity of flies (see Roháček \& Ševčík 2009). Photos by J. Ševčík 
personal collection of Tomáš Sikora (TSPC), which will ultimately be deposited in NMPC, in the NHRS, and in the Senckenberg Deutsches Entomologisches Institut (SDEI), Müncheberg, Germany. Morphological terms used here are in accordance with those applied to fungivorous Cecidomyiidae by Jaschhof \& Jaschhof $(2009,2013)$, and, with respect to wing veins, Jaschhof (2016). The arrangement of subfamilies follows the classification outlined by Gagné \& Jaschhof (2014); genera and species are listed alphabetically.

Other abbreviations used in the present paper are as follows:

$$
\begin{aligned}
& \mathrm{BR}=\text { Biosphere Reserve } \\
& \mathrm{NM}=\text { Nature Monument } \\
& \mathrm{NR}=\text { Nature Reserve } \\
& \mathrm{NNR}=\text { National Nature Reserve } \\
& \mathrm{NP}=\text { National Park } \\
& \mathrm{tg}=\text { tergite }
\end{aligned}
$$

\section{Results}

Class Insecta Linnaeus, 1758

Order Diptera Linnaeus, 1804

Infraorder Bibionomorpha Hennig, 1954

Family Cecidomyiidae Newman, 1834

Genus Glossostyles Jaschhof \& Sikora gen. nov. urn:1sid:zoobank.org:act:2FDD675F-C42E-4690-B867-11072038C604

\section{Type species}

Glossostyles perspicua gen. et sp. nov., described below.

\section{Diagnosis}

Adult morphology shows Glossostyles gen. nov. to be a typical member of the tribe Porricondylini, where it belongs to the large group of genera with 14 male flagellomeres and without basitarsal spines (group Aa in Jaschhof \& Jaschhof 2013). The unadorned but massive construction of the male genitalia (Fig. 3D) makes Glossostyles gen. nov. distinctive, with the particulars as follows. The gonocoxae are fully merged ventromedially and lack processes at the posterior edge; the gonostyli are disproportionally large and have no apical structure other than a sparse row of inconspicuous spines; the parameres are fused to form a tegmen, which encloses the ejaculatory apodeme dorsally as a weakly sclerotized semicylinder whose shape is elongate-trapezoid in ventral view. Similarly, large gonostyli and gonocoxae are found in other genera of Porricondylini, such as Pseudepidosis Mamaev, 1966 and Claspettomyia Grover, 1964, but there they are modified, the gonostyli with apical teeth and/or subapical swellings, and the gonocoxae with a ventral emargination and various processes. Unlike in Glossostyles gen. nov., the parameres in Pseudepidosis and Claspettomyia are strongly sclerotized, and are either separated from each other or complexly built. Claspettomyia is peculiar among these three genera for having 13 instead of 14 male flagellomeres.

\section{Etymology}

The name Glossostyles is composed of the Greek words 'glossa', for tongue, and 'stylos', for stylus, with reference to the distinctive tongue-shape of the gonostyli. Gender is feminine. 


\section{Notes on relationship}

Obvious similarities in the structure of the gonostyli and gonocoxae suggest that Glossostyles gen. nov. is most closely related to Claspettomyia. In both genera the gonostyli are enormously large, constricted beyond the basal apophyses, which are well developed, and clearly broadened further distally, while the massive gonocoxae are much broader than long.

Glossostyles perspicua Jaschhof \& Sikora gen. et sp. nov. urn:1sid:zoobank.org:act:5C7275CB-7B7F-4FAD-808F-3E346206447A

Fig. 3A-F

\section{Diagnosis}

This species differs from the other Porricondylini in the characters referred to in the generic diagnosis of Glossostyles gen. nov. In particular, the tongue-shaped gonostyli, which are unusually large and directed ventromedially, make G. perspicua gen. et sp. nov. unmistakable.

\section{Etymology}

The species epithet 'perspicua' is a Latin adjective, meaning 'unmistakable'.

\section{Type material}

\section{Holotype}

CZECH REPUBLIC: §ૈ, Bohemia, Šumava Mts, Zhůřské slatě, peat-bog, 24 Jun.-28 Jul. 2000, MT, M. Barták and Š. Kubík leg. (NMPC-35000).

\section{Paratype}

CZECH REPUBLIC: О̊, Bohemia, Šumava Mts, Horská Kvilda, spruce forest, 20 May-17 Jun. 1999, MT, M. Barták and J. Roháček leg. (NMPC-35001).

\section{Other material studied}

SWEDEN: đૈ, Södermanland, Tyresta NP, Naturvårdsverket inventory site "1 south", 15 Jul.-26 Aug. 2000, B. Viklund, L.-O. Wikars and H. Ahnlund leg. (NHRS-GULI000022473); 14 $\widehat{\jmath}, 12$ 우 , same locality, site "4", 10-26 May 2001 (NHRS-GULI000022471, -472, -474-479 and SDEI).

\section{Description}

\section{Male}

Body. Size up to $2.2 \mathrm{~mm}$.

HeAd. Postfrons asetose. Eye bridge 3-4 ommatidia long dorsally. Antenna slightly longer than body. Scape and pedicel lighter than flagellum. Circumfila on flagellomeres 1-14, evenly ring-shaped. Neck of fourth flagellomere 1.2 times as long as node (Fig. 3E). Palpus 1.3 times as long as head height, 4 subcylindrical segments, fourth segment longest of all.

Thorax. Anepisternum and anepimeron setose. Wing (Fig. 3A) longer than body. Length/width 2.8. Rs strongly oblique, almost in line with $R_{5}$. Btv sinuous. A remnant $M_{1+2}$ present at wing margin. $M_{4}$ weak, approaches $\mathrm{CuA}$. Legs densely covered with narrow scales, conspicuously light setae on third to fifth tarsomeres (therefore tarsi white-tipped). Claws moderately curved, 1 large and 2-4 smaller teeth basally. Empodia broad, as long as claws.

AвDOMEn. Sclerites entire, setae long, aligned on posterior margin, dispersed elsewhere. Pleural membrane sparsely setose. 

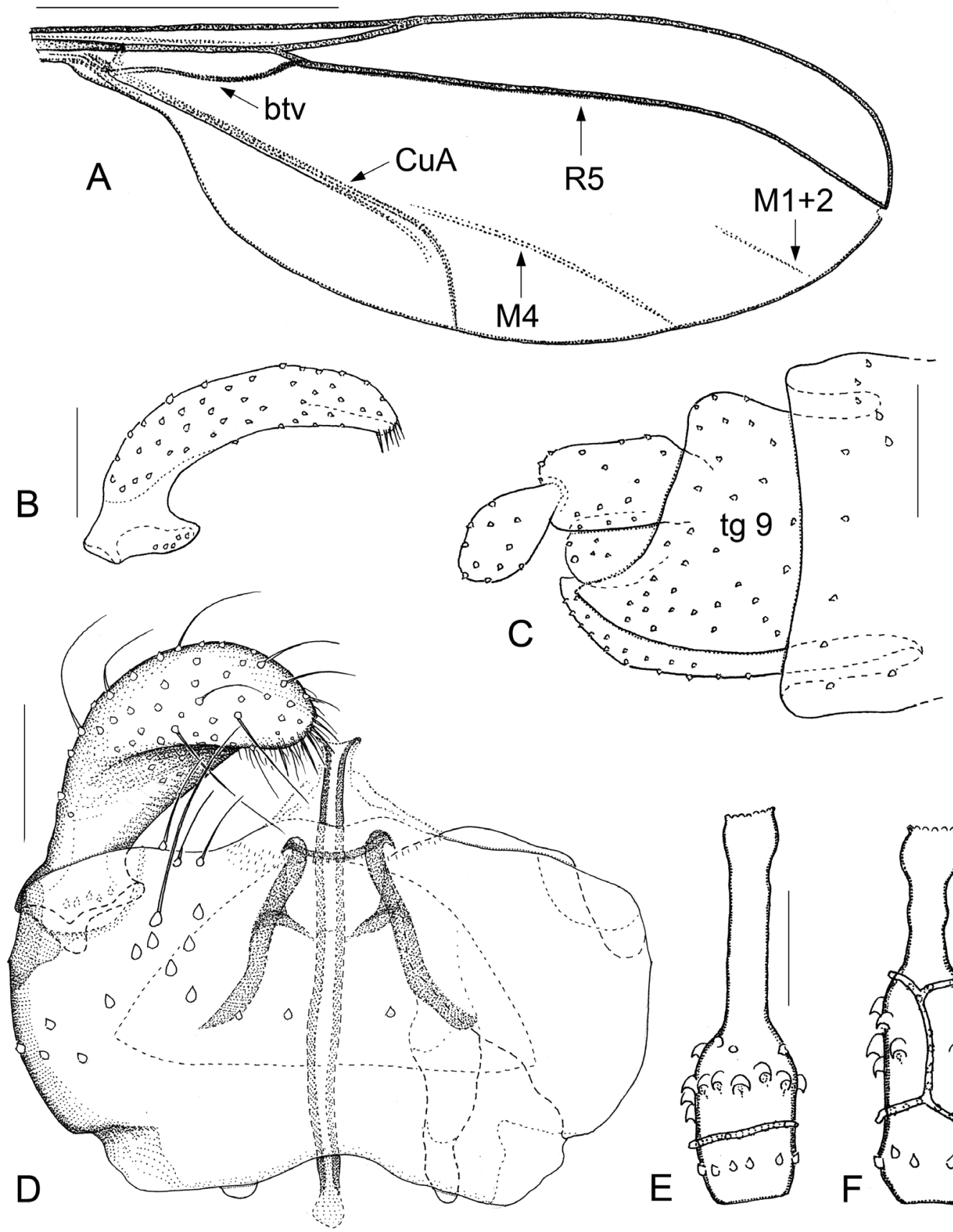

Fig. 3. Morphology of Glossostyles perspicua Jaschhof \& Sikora gen. et sp. nov. A. Wing, setae omitted ( 9 from Tyresta). B. Gonostylus, lateral (specimen from Tyresta). C. Female genitalia, lateral view (specimen from Tyresta). D. Male genitalia, ventral (holotype). E. Male fourth flagellomere, lateral view (holotype). F. Female fourth flagellomere, lateral (specimen from Tyresta). Scale bars: A=1 mm; $\mathrm{B}-\mathrm{F}=0.05 \mathrm{~mm}$. 
Genitalia (Fig. 3D). Ninth tergite subtrapezoid. Gonocoxae broad, sparsely setose ventrally, with membranous, glabrous lobe medially on posterior edge; apodemes thick, long. Gonostylus massive, but appears surprisingly slender in strict lateral view (Fig. 3B), slightly curved, longer than gonocoxa, broadest at mid-length, constricted subbasally, on apex a few thin spines intermingled with long microtrichia, setae of various lengths elsewhere. Tegmen subtrapezoid in ventral view, with narrow collar apically, small apodemes beyond mid-length. Ejaculatory apodeme longer than gonocoxites, moderately sclerotized.

\section{Female}

Body. Size up to $2.8 \mathrm{~mm}$.

HEAD. Antenna with 11 flagellomeres. Flagellomeres with elongate-subcylindrical nodes, distinct necks, circumfila as in Fig. 3F. Neck of fourth flagellomere more than half as long as node.

Genitalia (Fig. 3C). As typical for Porricondylini, including unusually large ninth tergite, 2-segmented dorsal lamella. Disticercus slightly smaller than basicercus.

\section{Note on identification}

The specimens of G. perspicua gen. et sp. nov. from Tyresta were initially identified as an unnamed species of Porricondylini by Voldemars Spungis, University of Latvia, who worked, but never published, on the Porricondylinae from the Tyresta insect inventory in the early 2000s. Due to the rather poor state of preservation, those specimens remained undescribed in Jaschhof \& Jaschhof's (2013) revision of Swedish Porricondylinae.

\section{New faunistic records}

Lestremiinae Rondani, 1840

Anaretella Enderlein, 1911

Anaretella iola Pritchard, 1951

\section{Material}

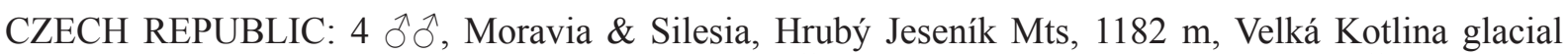
cirque, 26 Jun.-25 Jul. 2006, MT, J. Roháček and J. Ševčík leg. (TSPC); 2 ððત, Bohemia, Šumava Mts, Zhưřské slatě, 18 May-16 Jun. 1999, MT, M. Barták and Š. Kubík leg. (TSPC).

\section{Distribution}

Widely distributed throughout the Holarctic realm (Gagné \& Jaschhof 2014). New to CZ.

Micromyinae Rondani, 1856

Aprionus Kieffer, 1894

Aprionus cornutus Berest, 1986

\section{Material}

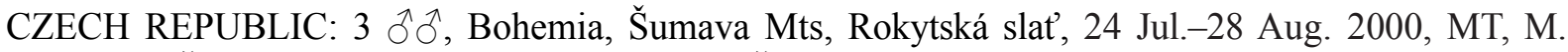
Barták and Š. Kubík leg. (TSPC); 1 Oૈ, Bohemia, Šumava Mts, Nová Hůrka, 13 May-24 Jun. 2000, MT, M. Barták and Š. Kubík leg. (TSPC). 


\section{Distribution}

Recorded in several European countries, from Norway to Ukraine (Gagné \& Jaschhof 2014). New to CZ.

\section{Aprionus dalarnensis Mamaev, 1998}

\section{Material}

CZECH REPUBLIC: 1 J̄, Moravia and Silesia, Hrubý Jeseník Mts, Rejvíz NNR, 27 May-26 Jun. 2005, MT, J. Roháček and J. Ševčík leg. (TSPC).

\section{Distribution}

Until now recorded only from northern Europe (Gagné \& Jaschhof 2014). New to CZ.

$$
\text { Aprionus denticulus Berest, } 1986
$$

\section{Material}

CZECH REPUBLIC: 1 đ̂, Bohemia, Šumava Mts, Zhůřské slatě, 18 May-16 Jun. 1999, MT, M. Barták and Š. Kubík leg. (TSPC).

\section{Distribution}

European in distribution (Gagné \& Jaschhof 2014). New to CZ.

Aprionus dentifer Mamaev, 1965

\section{Material}

CZECH REPUBLIC: 3 $\widehat{\jmath}$, Bohemia, Šumava Mts, Nová Hůrka, 13 May-24 Jun. 2000, MT, M. Barták and Š. Kubík leg. (TSPC).

\section{Distribution}

Widely distributed in Europe (Gagné \& Jaschhof 2014). New to CZ.

Aprionus flavidus (Winnertz, 1870)

\section{Material}

CZECH REPUBLIC: 1 O̊, Moravia and Silesia, Šilheřovice, Černý les II. NR, 4 Sep. 2015, SW, T. Sikora and J. Ševčík leg. (TSPC).

\section{Distribution}

Widely distributed and very common in Europe (Gagné \& Jaschhof 2014). New to CZ.

Aprionus halteratus (Zetterstedt, 1852)

\section{Material}

SLOVAK REPUBLIC: 1 ð̊, Muránská planina NP, Havrania dolina, 1 Oct. 2015, T. Sikora leg. (TSPC).

\section{Distribution}

Common and widely distributed in Europe (Gagné \& Jaschhof 2014). New to SK. 


\section{Aprionus inquisitor Mamaev, 1963}

\section{Material}

CZECH REPUBLIC: 1 §̊, Moravia and Silesia, Hrubý Jeseník Mts, Rejvíz NNR, 27 May-26 Jun. 2005, MT, J. Roháček and J. Ševčík leg. (TSPC).

\section{Distribution}

Widely distributed in Palaearctic region (Gagné \& Jaschhof 2014). New to CZ.

\section{Aprionus lindgrenae Jaschhof, 2015}

\section{Material}

SLOVAK REPUBLIC: 1 đ, Pol’ana BR, Hrončecký grúň NNR, 24 May-23 Jun. 2005, MT, J. Roháček and J. Ševčík leg. (TSPC).

\section{Distribution}

Recently described from Sweden and Germany (Jaschhof \& Jaschhof 2015), probably more widely distributed in Europe. New to SK.

$$
\text { Aprionus oligodactylus Jaschhof, } 2009
$$

\section{Material}

CZECH REPUBLIC: 3 §̊̄, Moravia and Silesia, Rejvíz NNR, 27 May-26 Jun. 2005, MT, J. Roháček and J. Ševčík leg. (TSPC); 1 đ̂, Bohemia, Šumava Mts, Nová Hůrka, 13 May-24 Jun. 2000, MT, M. Barták and Š. Kubík leg. (TSPC).

\section{Distribution}

Recently described from northern Europe (Jaschhof \& Jaschhof 2009). New to CZ.

\section{Aprionus pigmentalis Mamaev, 1998}

\section{Material}

CZECH REPUBLIC: 1 §ૈ, Moravia and Silesia, Hrubý Jeseník Mts, 1182 m, Velká Kotlina glacial cirque, 26 Jun.-25 Jul. 2006, MT, J. Roháček and J. Ševčík leg. (TSPC).

\section{Distribution}

Palaearctic in distribution (Gagné \& Jaschhof 2014). New to CZ.

$$
\text { Aprionus spiniger (Kieffer, 1894) }
$$

\section{Material}

SLOVAK REPUBLIC: 1 đે, Bukovské vrchy Mts, Runina, 29 Jun.-3 Jul. 2015, SW, T. Sikora leg. (TSPC).

\section{Distribution}

Common and widely distributed in the Holarctic realm (Gagné \& Jaschhof 2014), including CZ and SK (Skuhravá 2004, 2009). An additional record from north-east Slovakia. 
Bryomyia Kieffer, 1895

Bryomyia apsectra Edwards, 1938

\section{Material}

CZECH REPUBLIC: 1 ภ̂, Moravia and Silesia, Šilheřovice, Černý les II. NR, 23 Oct. 2015, SW, T. Sikora and J. Ševčík leg. (TSPC); 1 Õ, Moravia and Silesia, Podyjí NP, Terasy, 3 May-2 Jun. 2003, MT, M. Barták and Š. Kubík leg. (TSPC); 2 đ̊̄ Kotlina glacial cirque, 26 Jun.-25 Jul. 2006, MT, J. Roháček and J. Ševčík leg. (TSPC).

\section{Distribution}

A widespread Palaearctic species (Gagné \& Jaschhof 2014). New to CZ.

Bryomyia bergrothi Kieffer, 1895

\section{Material}

CZECH REPUBLIC: 3 ฮิð̄, Bohemia, Šumava Mts, Rokytská slat', 24 Jun.-28 Aug. 2000, MT, M. Barták and Š. Kubík leg. (TSPC); 1 Õ, Moravia \& Silesia, Šilheřovice, Černý les II. NR, 4 Sep. 2015, SW, J. Ševčík and T. Sikora leg. (TSPC).

SLOVAK REPUBLIC: 1 đ, Muránská planina NP, Pol’udnica NNR, 30 Sep. 2015, MT, J. Roháček and J. Ševčík leg. (TSPC).

\section{Distribution}

Very common and widespread in the Palaearctic region (Gagné \& Jaschhof 2014). New to CZ and SK.

Bryomyia gibbosa (Felt, 1907)

\section{Material}

CZECH REPUBLIC: 1 đึ, Moravia and Silesia, Hrubý Jeseník Mts, Rejvíz NNR, 21 Jul.-5 Sep. 2005, MT, J. Roháček and J. Ševčík leg. (TSPC); 1 O̊, Bohemia, Rokytská slat', 24 Jun.-28 Jul. 2005, MT, M.

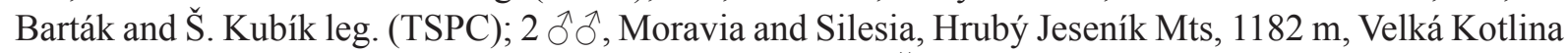
glacial cirque, 26 Jun.-25 Jul. 2006, MT, J. Roháček and J. Ševčík leg. (TSPC).

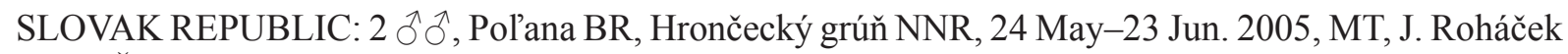
and J. Ševčík leg. (TSPC).

\section{Distribution}

Holarctic in distribution (Gagné \& Jaschhof 2014). New to CZ and SK.

Bryomyia helmuti Jaschhof, 1998

\section{Material}

SLOVAK REPUBLIC: 1 Oૈ, Pol’ana BR, Hrončecký grúň NNR, 10 Jul.-9 Oct. 2005, MT, J. Roháček and J. Ševčík leg. (TSPC).

\section{Distribution}

Previously known only from the type locality in Germany (Gagné \& Jaschhof 2014). New to SK. 
Campylomyza Meigen, 1818

Campylomyza dilatata Felt, 1907

\section{Material}

CZECH REPUBLIC: 1 đ̊, Bohemia, Šumava Mts, Zhůřské slatě, 18 May-16 Jun. 1999, MT, M. Barták and Š. Kubík leg. (TSPC).

\section{Distribution}

Widespread in Holarctic realm (Gagné \& Jaschhof 2014). New to CZ.

Campylomyza paenebicolor Jaschhof, 2009

\section{Material}

CZECH REPUBLIC: 1 ふึ, Moravia and Silesia, Podyjí NP, Havraníky, 27 Sep.-14 Nov. 2001, MT, M. Barták and Š. Kubík leg. (TSPC).

\section{Distribution}

Widely distributed in Europe (Gagné \& Jaschhof 2014). New to CZ.

Catocha incisa Jaschhof, 2009

\section{Material}

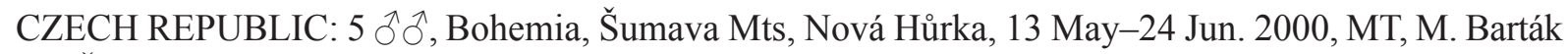
and Š. Kubík leg. (TSPC).

\section{Distribution}

Probably widely distributed in Europe (Jaschhof \& Jaschhof 2009). New to CZ.

Heterogenella Mamaev, 1963

Heterogenella hybrida Mamaev, 1963

\section{Material}

CZECH REPUBLIC: 1 đ̊, Bohemia Šumava Mts, Nová Hůrka, 13 May-24 Jun. 2000, MT, M. Barták and Š. Kubík leg. (TSPC); 1 O̊, Bohemia, Šumava Mts, Horská Kvilda, 21 Aug.-29 Sep. 1999, MT, M. Barták and Š. Kubík leg. (TSPC).

\section{Distribution}

Palaearctic in distribution (Gagné \& Jaschhof 2014). New to CZ.

Micromya Rondani, 1840

Micromya lucorum Rondani, 1840

\section{Material}

CZECH REPUBLIC: 3 ふึَ̄, Moravia and Silesia, Podyjí NP, Havraníky, 27 Sep.-14 Nov. 2001, MT, M. Barták and Š. Kubík leg. (TSPC); 1 đ̊, Bohemia Šumava Mts, Nová Hůrka, 13 May-24 Jun. 2000, MT, M. Barták and Š. Kubík leg. (TSPC). 


\section{Distribution}

The only member of the genus Micromya Rondani, 1840 in Europe (Gagné \& Jaschhof 2014). An additional record for CZ (see Skuhravá 1994, 2009).

Monardia Kieffer, 1895

Monardia (Xylopriona) atra (Meigen, 1804)

\section{Material}

CZECH REPUBLIC: 1 ô, Moravia and Silesia, Podyjí NP, Havraníky, 27 Sep.-14 Nov. 2001, MT,

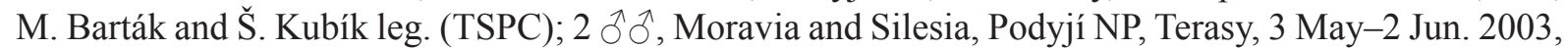
MT, M. Barták and Š. Kubík leg. (TSPC); 1 ô, Moravia and Silesia, Podyjí NP, Braitava-letohrádek, 13 May-1 Jun. 2001, MT, M. Barták and Š. Kubík (TSPC).

SLOVAK REPUBLIC: 1 đ̊, Muránská planina NP, Muránský hrad, 30 Oct. 2015, SW, J. Roháček leg. (TSPC); 4 ổ, Muránská planina NP, Mokrá Pol’ana NR, 1 Oct. 2015, SW, J. Roháček leg. (TSPC); 2 §ð̊, Muránská planina NP, Pol'udnica NNR, 30 Sep. 2015, MT, J. Roháček and J. Ševčík leg. (TSPC).

\section{Distribution}

Widely distributed in the Holarctic realm (Gagné \& Jaschhof 2014). Additional records for CZ and SK (cf. Skuhravá 1994, 2009).

Monardia (Monardia) obsoleta Edwards, 1938

\section{Material}

CZECH REPUBLIC: 2 $\widehat{\jmath}$, Moravia and Silesia, Šilheřovice, Černý les II. NR, adults emerged 15 Nov. 2015, reared from larvae found in mould on Royoporus badius, J. Ševčík and T. Sikora leg. (TSPC).

\section{Distribution}

Widely distributed in Europe (Gagné \& Jaschhof 2014). Reported as new to CZ by Ševčík (2010), who found larvae living in mould on the polypore fungus Royoporus badius. Another rearing record from $\mathrm{CZ}$ is presented here.

\section{Monardia (Xylopriona) toxicodendri (Felt, 1907)}

\section{Material}

CZECH REPUBLIC: 1 §ึ, Moravia and Silesia, Bílé Karpaty Mts, NR Kútky, 26 Jun. 2008, MT, J. Ježek leg. (TSPC).

\section{Distribution}

Holarctic in distribution (Gagné \& Jaschhof 2014). First recorded in CZ by Skuhravá (1997), another Czech record.

Monardia (Xylopriona) unguifera Berest \& Mamaev, 1997

\section{Material}

CZECH REPUBLIC: 1 đ̊, Moravia and Silesia, Staré Město nr. Frýdek-Místek, Profil Morávky NM, 12 Sep. 2015, SW, T. Sikora leg. (TSPC). 


\section{Distribution}

A rarely collected species, previously known from a few specimens collected in Germany, Ukraine and Finland (Gagné \& Jaschhof 2014). New to CZ.

Neurolyga Rondani, 1840

Neurolyga acuminata Jaschhof, 2009

\section{Material}

CZECH REPUBLIC: 2 $\widehat{\partial}$, Moravia and Silesia, Hrubý Jeseník Mts, 1182 m, Velká Kotlina glacial cirque, 26 Jun.-25 Jul. 2006, MT, J. Roháček and J. Ševčík leg. (TSPC).

\section{Distribution}

Palaearctic in distribution (Gagné \& Jaschhof 2014). New to CZ.

Neurolyga excavata (Yukawa, 1967)

\section{Material}

CZECH REPUBLIC: 1 ðึ, Moravia and Silesia, Hrubý Jeseník Mts, Rejvíz NNR, 21 Jul.-5 Sep. 2004,

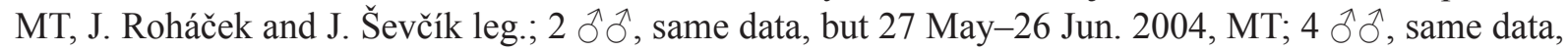
but 2 Aug.-28 Sep. 2005, MT (all TSPC).

\section{Distribution}

Widely distributed in the Palaearctic region (Gagné \& Jaschhof 2014). New to CZ.

Neurolyga interrupta Jaschhof, 2009

\section{Material}

CZECH REPUBLIC: 1 ๙ิ, Moravia and Silesia, Hrubý Jeseník Mts, 1182 m, Velká Kotlina glacial cirque, 26 Jun.-25 Jul. 2006, MT, J. Roháček and J. Ševčík leg. (TSPC).

\section{Distribution}

Previously known from northern Europe (Gagné \& Jaschhof 2014). New to CZ.

Peromyia Kieffer, 1894

\section{Peromyia bidentata Berest, 1988}

\section{Material}

CZECH REPUBLIC: 1 đ̊, Moravia and Silesia, Podyjí NP, Ledové sluje, 26 Jun.-31 Jul. 2002, MT, M. Barták and Š. Kubík leg. (TSPC).

\section{Distribution}

A rarely collected Palaearctic species (Gagné \& Jaschhof 2014). New to CZ. 


\section{Material}

CZECH REPUBLIC: 2 $\widehat{\jmath}$, Moravia and Silesia, Podyjí NP, Ledové sluje, 26 Jun.-31 Jul. 2002, MT, M. Barták and Š. Kubík leg. (TSPC).

\section{Distribution}

Holarctic in distribution (Gagné \& Jaschhof 2014). Previously reported from CZ by Ševčík (2010). This is an additional record for $\mathrm{CZ}$.

Peromyia ramosa (Edwards, 1938)

\section{Material}

CZECH REPUBLIC: 1 ổ, Moravia and Silesia, Podyjí NP, Ledové sluje, 26 Jun.-31 Jul. 2002, MT, M. Barták and Š. Kubík leg. (TSPC).

\section{Distribution}

Widely distributed in the Palaearctic region (Gagné \& Jaschhof 2014). New to CZ.

$$
\text { Polyardis Pritchard, } 1947
$$

Polyardis adela Pritchard, 1947

\section{Material}

SLOVAK REPUBLIC: 1 đ, Muránská planina NP, Studňa, 4 Sep.-10 Oct. 2014, MT, J. Roháček and J. Ševčík leg. (TSPC); 1 Oૈ, Bukovské vrchy Mts, Runina, 29 Jun.-3 Jul. 2015, SW, T. Sikora leg. (TSPC).

\section{Distribution}

Holarctic in distribution (Gagné \& Jaschhof 2014). New to SK.

Skuhraviana Mamaev, 1963

\section{Skuhraviana triangulifera Mamaev, 1963}

\section{Material}

CZECH REPUBLIC: 2 $\widehat{\partial}$, Moravia and Silesia, Šilheřovice, Černý les II. NR, 4 Sep. 2015, SW, J. Ševčík and T. Sikora leg. (TSPC).

\section{Distribution}

Holarctic in distribution (Gagné \& Jaschhof 2014). New to CZ.

$$
\begin{gathered}
\text { Winnertziinae Panelius, } 1965 \\
\text { Diallactia Gagné, } 2004
\end{gathered}
$$

Diallactia crocea (Kieffer, 1894)

\section{Material}

CZECH REPUBLIC: 3 ổ, Bohemia, Šumava Mts, Nová Hůrka, 16 Jun.-22 Jul. 1999, MT, M. Barták and Š. Kubík leg.; 1 ð̊, same data, but 13 May-24 Jun. 2000, MT (both TSPC). 


\section{Distribution}

Common and widely distributed in Europe, also occurring in the the Near East (Gagné \& Jaschhof 2014). New to CZ.

Ekmanomyia Jaschhof, 2013

Ekmanomyia svecica Jaschhof, 2013

\section{Material}

CZECH REPUBLIC: 1 ภ, Moravia and Silesia, Hrubý Jeseník Mts, 1182 m, Velká Kotlina glacial cirque, 26 Jun.-25 Jul. 2006, MT, J. Roháček and J. Ševčík leg. (TSPC); 1 Oૈ, Moravia and Silesia, Podyjí NP, Fládnická chata, 2 Jul.-3 Aug. 2004, MT, M. Barták and Š. Kubík leg. (TSPC).

\section{Distribution}

Recently described from Sweden (Jaschhof \& Jaschhof 2013). New to CZ.

Winnertzia Rondani, 1860

Winnertzia globifera Mamaev, 1963

\section{Material}

SLOVAK REPUBLIC: 1 đે, Muránská planina NP, Studňa, 14 Jul.-4 Sep. 2014, MT, J. Roháček and J. Ševčík leg. (TSPC); 1 đ̃, Muránská planina NP, Hrdzavá dolina, 28 Jun.-26 Jul. 2010, MT, J. Roháček and J. Ševčík leg. (SDEI); 2 ổ ô, Pol’ana BR, Hrončecký grúň NNR, 24 May-23 Jun. 2005, MT, J. Roháček and J. Ševčík (TSPC); 1 Ô, Pol'ana BR, Hrončecký grúň NNR, 10 Aug.-9 Oct. 2005, MT, J. Roháček and J. Ševčík (TSPC).

\section{Distribution}

This species was recently recorded from CZ by Mantič et al. (2015). New to SK.

Winnertzia parvispina Jaschhof, 2013

\section{Material}

SLOVAK REPUBLIC: 1 Õ, Muránská planina NP, Muránská Lehota, 22 Jun.-25 Jul. 2012, MT, J. Roháček and J. Ševčík leg. (TSPC).

\section{Distribution}

Previously known only from Sweden (Gagné \& Jaschhof 2014). New to SK.

Winnertzia xylostei Mamaev, 1963

\section{Material}

CZECH REPUBLIC: 1 §ึ, Moravia and Silesia, Bílé Karpaty Mts, Kladénka, 3 Jun. 2008, MT, J. Ježek (SDEI).

SLOVAK REPUBLIC: 1 đ, Muránská planina NP, Nad Javorníčkovou dolinou, 13 Jul. 2015, MT, J. Roháček and J. Ševčík leg. (TSPC). 


\section{Distribution}

A common Palaearctic species (Gagné \& Jaschhof 2014). New to CZ and SK.

$$
\begin{gathered}
\text { Porricondylinae Kieffer, } 1913 \\
\text { Asynapta Loew, } 1850
\end{gathered}
$$

Asynapta inflata Spungis, 1988

\section{Material}

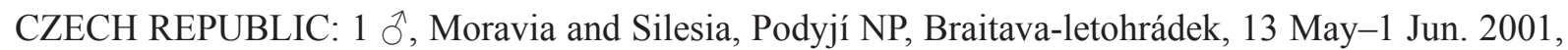
MT, M. Barták and Š. Kubík leg. (TSPC).

\section{Distribution}

This species was hitherto known only from Sweden, Latvia and Ukraine (Gagné \& Jaschhof 2014). New to $\mathrm{CZ}$.

$$
\text { Asynapta strobi (Kieffer, 1920) }
$$

\section{Material}

CZECH REPUBLIC: $1 \hat{\jmath}$, Moravia and Silesia, Hrubý Jeseník Mts, 1182 m, Velká Kotlina glacial cirque, 4 Sep.-24 Nov. 2006, MT, J. Roháček and J. Ševčík leg. (TSPC).

SLOVAK REPUBLIC: 1 ô, Muránská planina NP, Fabova hol’a NR, 16 Jun.-25 Aug. 2009, MT, J. Roháček and J. Ševčík leg. (SDEI).

\section{Distribution}

Widely distributed in the Palaearctic region (Gagné \& Jaschhof 2014). New to SK.

$$
\text { Camptomyia Kieffer, } 1894
$$

\section{Camptomyia abnormis Mamaev, 1961}

\section{Material}

CZECH REPUBLIC: 1 đ, Moravia and Silesia, Podyjí NP, Terasy MT, 3 May-2 Jun. 2003, M. Barták and Š. Kubík leg. (TSPC).

\section{Distribution}

Widely distributed in Europe (Gagné \& Jaschhof 2014). New to CZ.

Camptomyia corticalis Loew, 1851

\section{Material}

SLOVAK REPUBLIC: 1 O̊, Muránská planina NP, Pol’udnica NNR, 8 Jul. 2015, MT, J. Roháček and J. Ševčík leg. (TSPC).

\section{Distribution}

Previously recorded from SK by Skuhravá \& Košel (1995) as Camptomyia innotata Kieffer, 1894; another record for SK is presented here. 
Camptomyia flavocinerea Panelius, 1965

\section{Material}

CZECH REPUBLIC: 1 ð̊, Moravia and Silesia, Podyjí NP, Terasy, 3 May-2 Jun. 2003, MT, M. Barták and Š. Kubík leg. (TSPC); 1 ð̃, Moravia and Silesia, Hrubý Jeseník Mts, 1182 m, Velká Kotlina glacial cirque, 26 Jun.-27 Jul. 2006, MT, J. Roháček and J. Ševčík leg. (TSPC).

\section{Distribution}

This species has recently been reported from both the Czech Republic and Slovakia by Mantič et al. (2015). Additional records for CZ.

\section{Camptomyia gigantea Spungis, 1989}

\section{Material}

SLOVAK REPUBLIC: 2 $\widehat{\partial}$, Muránská planina NP, Čertova dolina, 4 Aug.-19 Sep. 2013, J. Roháček and J. Ševčík leg. (TSPC); 2 đ̂̃, Muránská planina NP, Poluudnica NNR, 21 Jun.-9 Aug. 2013, MT, J. Roháček and J. Ševčík leg. (TSPC); 2 đ̂đ̄, Pol’ana BR, Hrochot', Beňova dolina, 24 May-11 Jul. 2007, MT, J. Roháček and J. Ševčík (TSPC).

\section{Distribution}

Until now this species has been known only from Sweden and Latvia (Gagné \& Jaschhof 2014). New to central Europe including SK.

Camptomyia multinoda (Felt, 1908)

\section{Material}

SLOVAK REPUBLIC: 1 đ, Pol’ana BR, Hrončecký grúň NNR, 10 Aug.-9 Oct. 2005, MT, J. Roháček and J. Ševčík leg. (TSPC); 1 Oૈ, Muránská planina NP, Šiance, 4 Sep.-26 Oct. 2012, MT, J. Roháček and J. Ševčík leg. (TSPC).

\section{Distribution}

Holarctic in distribution (Gagné \& Jaschhof 2014). New to SK.

Camptomyia spinifera Mamaev, 1961

\section{Material}

SLOVAK REPUBLIC: 1 §̂, Pol’ana BR, Hrončecký grúň NNR, 10 Aug.-9 Oct. 2005, MT, J. Roháček and J. Ševč́k leg. (TSPC).

\section{Distribution}

Reported as new to CZ by Skuhravá (2004). New to SK.

Camptomyia ulmicola Mamaev, 1961

\section{Material}

CZECH REPUBLIC: 1 $\widehat{\jmath}$, Moravia and Silesia, Staré Město nr. Frýdek-Místek, Profil Morávky NM, 12 Sep. 2015, SW, T. Sikora leg. (TSPC). 


\section{Distribution}

Previously known mostly from northern Europe (Gagné \& Jaschhof 2014). New to CZ.

Cassidoides Mamaev, 1960

Cassidoides fulviventris (Mamaev, 1964)

\section{Material}

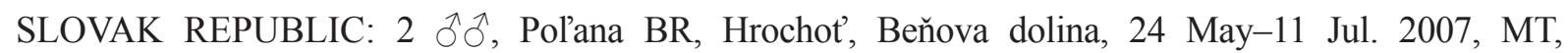
J. Roháček \& J. Ševčík leg. (TSPC).

\section{Distribution}

Widely distributed in the Palaearctic region (Gagné \& Jaschhof 2014). New to SK.

\section{Cassidoides fulvus (Kieffer, 1896)}

\section{Material}

SLOVAK REPUBLIC: 1 ふૈ, Pol'ana BR, Hrochot', Beňova dolina, 24 May-11 Jul. 2007, MT, J. Roháček and J. Ševčík leg. (TSPC).

\section{Distribution}

Holarctic in distribution (Gagné \& Jaschhof 2014). New to SK.

$$
\text { Claspettomyia Grover, } 1964
$$

Claspettomyia hamata (Felt, 1907)

\section{Material}

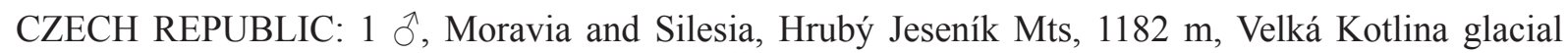
cirque, 9-26 Jun. 2006, MT, J. Roháček and J. Ševčík leg. (SDEI); 3 ỗ 25 Jul. 2006 (SDEI).

SLOVAK REPUBLIC: 2 đ̊̊̄, Muránská planina NP, Muránská Lehota, 22 Jun.-25 Jul. 2012, MT, J. Roháček and J. Ševčík leg. (TSPC).

\section{Distribution}

Holarctic in distribution (Gagné \& Jaschhof 2014). New to CZ and SK.

Coccopsilis Harris, 2004

Coccopsilis marginata (Meijere, 1901)

\section{Material}

SLOVAK REPUBLIC: 1 đ̊, Muránska planina NP, Hrdzavá dolina, 1 May-28 Jun. 2010, MT, J. Ševčík leg. (SDEI).

\section{Distribution}

Widely distributed in Europe (Gagné \& Jaschhof 2014). Previously recorded from SK by Skuhravá \& Košel (1995), another record for SK is presented here. 
Coccopsilis paneliusi (Yukawa, 1971)

\section{Material}

CZECH REPUBLIC: 1 $\widehat{\jmath}$, Moravia and Silesia, Hrubý Jeseník Mts, 1182 m, Velká Kotlina glacial cirque, 26 Jun.-25 Jul. 2006, MT, J. Roháček and J. Ševčík leg. (TSPC).

SLOVAK REPUBLIC: 1 ð, Muránská planina NP, Hrdzavá dolina, 14 May 2009, SW, J. Ševčík leg. (SDEI); 1 §̂, same locality, 28 Jun.-26 Jul. 2010, MT, J. Ševčík leg. (SDEI).

\section{Distribution}

Palaearctic in distribution (Gagné \& Jaschhof 2014). New to CZ and SK.

Dendrepidosis Mamaev, 1990

Dendrepidosis longipennis (Spungis, 1981)

\section{Material}

SLOVAK REPUBLIC: 1 O̊, Muránská planina NP, Šiance, 4 Sep.-26 Oct. 2012, MT, J. Roháček and J. Ševčík leg. (TSPC).

\section{Distribution}

A rarely collected European species (Gagné \& Jaschhof 2014). New to SK.

Dicerura Kieffer, 1898

Dicerura dispersa Jaschhof, 2013

\section{Material}

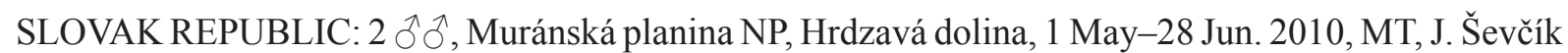
leg. (SDEI).

\section{Distribution}

This is the first record of this species outside the type locality in Sweden (Gagné \& Jaschhof 2014). New to SK.

Divellepidosis Fedotova \& Sidorenko, 2007

Divellepidosis hypoxantha (Panelius, 1965)

\section{Material}

CZECH REPUBLIC: 1 ภิ, Moravia and Silesia, Bílé Karpaty Mts, Kladénka, 3 Jun. 2008, MT, J. Ježek leg. (SDEI); 1 đ̃, Moravia and Silesia, Hrubý Jeseník Mts, 1182 m, Velká Kotlina glacial cirque, 26 Jun.-25 Jul. 2006, MT, J. Roháček and J. Ševčík leg. (TSPC).

\section{Distribution}

Widely distributed in Europe (Gagné \& Jaschhof 2014). New to CZ. 
Divellepidosis lutescens (Spungis, 1981)

\section{Material}

CZECH REPUBLIC: 1 đ̊, Moravia and Silesia, Šilheřovice, Černý les II. NR, 4 Sep. 2015, SW, J. Ševčík and T. Sikora leg. (TSPC).

SLOVAK REPUBLIC: 1 đ̊, Muránská planina NP, Šiance, 4 Sep.-26 Oct. 2012, MT, J. Roháček and J. Ševčík leg. (TSPC).

\section{Distribution}

Previously known from several European countries (Gagné \& Jaschhof 2014). New to central Europe including $\mathrm{CZ}$ and SK.

Divellepidosis pallescens (Panelius, 1965)

\section{Material}

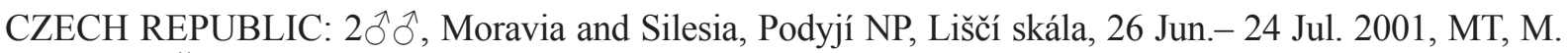
Barták and Š. Kubík leg. (TSPC).

SLOVAK REPUBLIC: 1 §,, Pol’ana BR, Hrochot', Beňova dolina, 24 May-11 Jul. 2007, MT, J. Roháček and J. Ševč́́k (TSPC).

\section{Distribution}

Previous records from northern Europe (Gagné \& Jaschhof 2014). New to CZ and SK.

Divellepidosis vulgata Jaschhof, 2013

\section{Material}

CZECH REPUBLIC: 1 đૈ, Moravia and Silesia, Podyjí NP, Čížovský rybník, 26 Jun.-24 Jul. 2001, MT, M. Barták and Š. Kubík leg. (TSPC); 1 Ō, Moravia and Silesia, Hrubý Jeseník Mts, Rejvíz NNR, 27 May-26 Jun. 2005, MT, J. Roháček and J. Ševčík leg. (TSPC).

\section{Distribution}

Recently described from Sweden (Jaschhof \& Jaschhof 2013). New to CZ.

Holoneurus Kieffer, 1895

\section{Holoneurus ciliatus Kieffer, 1896}

\section{Material}

SLOVAK REPUBLIC: 1 đ̂, Muránská planina NP, Nad Javorníčkovou dolinou, 5 May-11 Jun. 2015, MT, J. Roháček and J. Ševčík leg. (TSPC).

\section{Distribution}

Previously known from France and Sweden (Gagné \& Jaschhof 2014). New to central Europe including SK. 
Monepidosis Mamaev, 1966

Monepidosis pectinatoides Jaschhof, 2013

\title{
Material
}

CZECH REPUBLIC: 1 đ̊, Bohemia, Šumava Mts, Rokytská slat', 24 Jun.-28 Jul. 2000, MT, M. Barták and Š. Kubík leg. (TSPC).

\section{Distribution}

Only recently described from Sweden, but probably intermixed with M. pectinata Mamaev, 1966 by previous authors and thus more widespread (Jaschhof \& Jaschhof 2013). The first record of a species of Monepidosis in CZ.

\section{Neocolpodia Mamaev, 1964}

Neocolpodia gukasiani (Mamaev, 1990)

\section{Material}

CZECH REPUBLIC: 1 §ૈ, Moravia and Silesia, Bílé Karpaty Mts, Kladénka, 3 Jun. 2008, MT, J. Ježek leg. (SDEI).

\section{Distribution}

Previously known from Siberian Russia and Sweden (Gagné \& Jaschhof 2014). New to central Europe including CZ.

\author{
Paneliusia Jaschhof, 2013
}

Paneliusia albimanoides Jaschhof, 2013

\section{Material}

CZECH REPUBLIC: 1 đે, Moravia and Silesia, Hrubý Jeseník Mts, Rejvíz NNR, 2 Aug.-28 Sep. 2005, MT, J. Roháček and J. Ševčík leg. (TSPC); 2 ふ઼, Moravia and Silesia, Chvalíkovice, ex Phalaris arundinacea, adults emerged 20 Aug.-19 Sept. 2008, J. Roháček leg. (TSPC).

SLOVAK REPUBLIC: 1 đે, Muránská planina NP, Havrania dolina, 1 Oct. 2015, T. Sikora leg. (TSPC);

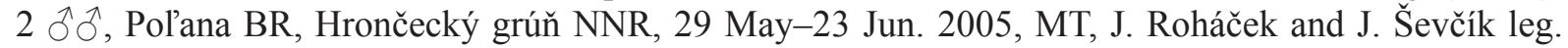
(TSPC); 1 đ̃, Muránská planina NP, Šiance, 4 Sep.-26 Oct. 2012, MT, J. Roháček and J. Ševčík leg. (TSPC); 1 đ̃, Muránská planina NP, Muránská Lehota, 5 Sep.-23 Oct. 2012, MT, J. Roháček and J. Ševčík leg. (TSPC).

\section{Distribution}

A widespread Palaearctic species (Jaschhof \& Jaschhof 2013). Two males from CZ were reared from reed canary grass, Phalaris arundinacea (see above). New to CZ and SK.

\section{Paneliusia aurantiaca (Panelius, 1965)}

\section{Material}

SLOVAK REPUBLIC: 1 đે, Muránská planina NP, Studňa, 4 Sep.-10 Oct. 2014, MT, J. Roháček and J. Ševčík leg. (TSPC). 


\section{Distribution}

Widely distributed in Europe (Gagné \& Jaschhof 2014). New to SK.

Parepidosis Kieffer, 1913

Parepidosis arcuata Mamaev, 1964

\section{Material}

CZECH REPUBLIC: 1 ð̊, Moravia and Silesia, Podyjí NP, Č́́žovský rybník, 26 Jun.-24 Jul. 2001, MT, M. Barták and Š. Kubík leg. (TSPC).

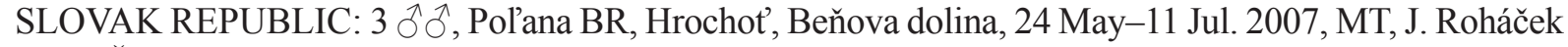
and J. Ševčík (TSPC).

\section{Distribution}

Widely distributed in Europe, also occurring in Uzbekistan (Gagné \& Jaschhof 2014). New to CZ and SK.

Parepidosis planistylata Jaschhof, 2013

\section{Material}

CZECH REPUBLIC: 1 đ̊, Moravia and Silesia, Hrubý Jeseník Mts, Rejvíz NNR, 21 Jun.-5 Oct. 2004, MT, J. Roháček and J. Ševčík leg. (TSPC).

\section{Distribution}

Recently described from Sweden (Jaschhof \& Jaschhof 2013). New to CZ.

Parepidosis venustior (Kieffer, 1901)

\section{Material}

SLOVAK REPUBLIC: 1 đે, Pol'ana BR, Hrončecký grúň NNR, 10 Aug.-9 Oct. 2005, MT, J. Roháček and J. Ševčík leg. (TSPC).

\section{Distribution}

Widely distributed in Europe (Gagné \& Jaschhof 2014). New to SK.

Porricondyla Rondani, 1840

Porricondyla colpodioides Mamaev, 1963

\section{Material}

CZECH REPUBLIC: 1 ð઼, Moravia and Silesia, Hrubý Jeseník Mts, Rejvíz NNR, 21 Jul.-5 Sep. 2004, MT, J. Roháček and J. Ševčík leg. (TSPC); 1 Ō, Moravia and Silesia, Bílé Karpaty Mts, NR Kútky, MT, 26 Jun. 2008 (TSPC); 1 ð̊, Moravia and Silesia, Hrubý Jeseník Mts, 1182 m, Velká Kotlina glacial cirque, 26 Jun.-25 Jul. 2006, MT, J. Roháček and J. Ševčík leg. (TSPC).

\section{Distribution}

Palaearctic in distribution (Gagné \& Jaschhof 2014). New to CZ. 
Porricondyla errabunda Mamaev, 2001

\section{Material}

CZECH REPUBLIC: 1 ð , Bohemia, Šumava Mts, Rokytská slat', 24 Jun.-28 Aug. 2000, MT, M. Barták

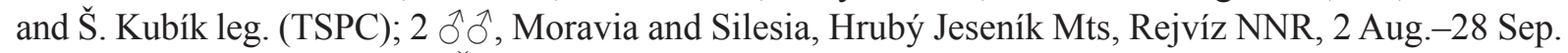
2005, MT, J. Roháček and J. Ševčík leg. (TSPC).

\section{Distribution}

Previously found to occur in western Siberia and Sweden (Gagné \& Jaschhof 2014). New to central Europe including CZ.

\section{Porricondyla microgona Jaschhof, 2013}

\section{Material}

SLOVAK REPUBLIC: 1 đૈ, Muránská planina NP, Fabova hol’a NR, 16 Jun.-25 Aug. 2009, MT, J. Ševč́́k leg. (SDEI).

\section{Distribution}

Recently described from Sweden (Gagné \& Jaschhof 2014). New to central Europe including SK.

Porricondyla neglecta Mamaev, 1965

\section{Material}

SLOVAK REPUBLIC: 1 đે, Muránská planina NP, Kučalach, 4 Sep. 2014, MT, J. Roháček and J. Ševčík leg. (TSPC).

\section{Distribution}

Known from several European countries (Gagné \& Jaschhof 2014), including CZ (see Skuhravá 1994). New to SK.

\section{Porricondyla nigripennis (Meigen, 1830)}

\section{Material}

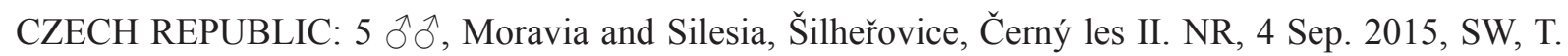
Sikora and J. Ševčík leg. (TSPC); 1 \&, Moravia and Silesia, Bílé Karpaty Mts, Kladénka, 3 Jun. 2008, MT, J. Ježek leg. (SDEI); 1 đ̂, Moravia and Silesia, Podyjí NP, Ledové sluje, 26 Jun.-31 Jul. 2002, MT, M. Barták and Š. Kubík leg. (TSPC).

SLOVAK REPUBLIC: 5 $\widehat{\jmath}, 1$ q, Muránská planina NP, Hrdzavá dolina, 1 May-26 Jul. 2010, MT, J. Ševčík leg. (SDEI); 2 đ̊, same locality, 14 May 2009, SW, J. Ševčík leg. (SDEI); 1 O̊, Muránská planina NP, Kučalach, 14 Jul.-3 Sep. 2014, MT, J. Roháček and J. Ševčík leg. (TSPC).

\section{Distribution}

A very common Holarctic species (Gagné \& Jaschhof 2014). These are the first records from Moravia and Silesia (CZ). 
SIKORA T. et al., Fungivorous Cecidomyiidae in the Czech and Slovak Republics

Porricondyla tetraschistica Mamaev, 1988

\section{Material}

SLOVAK REPUBLIC: 6 đ̊̊̄, Muránská planina NP, Šiance, 4 Sep.-26 Oct. 2012, MT, J. Roháček and J. Ševčík leg. (TSPC).

\section{Distribution}

A rarely collected species previously known only from Sweden and the Near East (Gagné \& Jaschhof 2014). New to central Europe including SK.

Rostellatyla Jaschhof, 2013

Rostellatyla rostellata (Panelius, 1965)

\section{Material}

CZECH REPUBLIC: 1 O̊, Moravia and Silesia, Šilheřovice, Černý les II. NR, 4 Sep. 2015, SW, J. Ševčík and T. Sikora leg. (TSPC).

\section{Distribution}

Widely distributed in Europe (Gagné \& Jaschhof 2014). New to CZ.

Serratyla Jaschhof, 2013

Serratyla pubescens (Walker, 1856)

\section{Material}

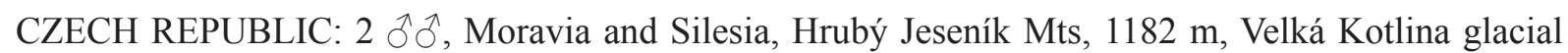
cirque, 26 Jun.-25 Jul. 2006, MT, J. Roháček and J. Ševčík leg. (TSPC).

SLOVAK REPUBLIC: 2 $\widehat{\jmath}$, Pol'ana BR, Hrončecký grúň NNR, 24 May-23 Jun. 2005, MT, J. Roháček and J. Ševčík leg. (TSPC); 1 đ̃, Muránská planina NP, Fabova hol’a NR, 16 Jun.-25 Aug. 2009, MT, J. Ševčík leg. (SDEI).

\section{Distribution}

Widely distributed in Europe (Gagné \& Jaschhof 2014). New to CZ and SK.

Schistoneurus Mamaev, 1964

Schistoneurus irregularis Mamaev, 1964

\section{Material}

CZECH REPUBLIC: 1 ð̊, Bohemia, Šumava Mts, Nová Hůrka, 13 May-24 Jun. 2000, MT, M. Barták and Š. Kubík leg. (TSPC); 4 ổ ô, Moravia and Silesia, Hrubý Jeseník Mts, 1182 m, Velká Kotlina glacial cirque, 26 Jun.-25 Jul. 2006, MT, J. Roháček and J. Ševčík leg. (TSPC).

SLOVAK REPUBLIC: 1 đ̊, Pol’ana BR, Hrochot', Beňova dolina, 24 May-11 Jul. 2007, MT, J. Roháček and J. Ševčík leg. (TSPC). 


\section{Distribution}

Previously recorded from northern and eastern Europe (Gagné \& Jaschhof 2014). New to central Europe including $\mathrm{CZ}$ and SK.

$$
\text { Spungisomyia Mamaev \& Zaitzev, } 1996
$$

Spungisomyia fenestrata Jaschhof, 2013

\section{Material}

CZECH REPUBLIC: 1 $\widehat{\jmath}$, Moravia and Silesia, Hruby Jeseník Mts, 1182 m, Velká Kotlina glacial cirque, MT, 9-26 Jun. 2006, J. Roháček and J. Ševčík leg. (SDEI).

\section{Distribution}

Recently described from Sweden (Gagné \& Jaschhof 2014). New to central Europe including CZ.

\section{Spungisomyia media (Spungis, 1981)}

\section{Material}

SLOVAK REPUBLIC: 1 đે, Pol’ana BR, Hrončecký grúň NNR, 24 May-23 Jun. 2005, MT, J. Roháček and J. Ševčík leg. (TSPC); 1 Ô, Pol’ana BR, Hrochot', Beňova dolina, 24 May-11 Jul. 2007, MT, J. Roháček and J. Ševčík leg. (TSPC).

\section{Distribution}

Palaearctic in distribution (Gagné \& Jaschhof 2014). New to SK.

$$
\text { Tetraneuromyia Mamaev, } 1964
$$

Tetraneuromyia hirticornis (Zetterstedt, 1850)

\section{Material}

CZECH REPUBLIC: 1 ô,, Moravia and Silesia, Šilheřovice, Černý les II. NR, 23 Oct. 2015, SW, J. Ševčík leg. (TSPC).

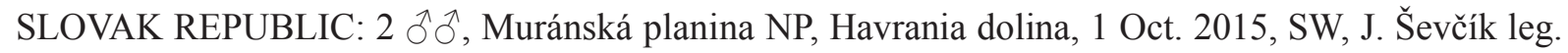
(TSPC).

\section{Distribution}

The most common and widely distributed species of Tetraneuromyia Mamaev, 1964 in Europe (Gagné \& Jaschhof 2014). New to CZ and SK.

Tetraneuromyia lamellata Spungis, 1987

\section{Material}

CZECH REPUBLIC: 1 đ̊, Bohemia, Šumava Mts, Rokytská slat', 24 Jun.-28 Jul. 2000, MT, M. Barták and Š. Kubík leg. (TSPC); 3 đ̊ ô, Moravia and Silesia, Hrubý Jeseník Mts, 1182 m, Velká Kotlina glacial cirque, 26 Jun.-25 Jul. 2006, MT, J. Roháček and J. Ševčík leg. (TSPC).

\section{Distribution}

Previously known from Sweden, Latvia and European Russia (Gagné \& Jaschhof 2014). New to central Europe including CZ. 
Tetraneuromyia lenticularis (Spungis, 1987)

\section{Material}

CZECH REPUBLIC: 1 $\widehat{\jmath}$, Moravia and Silesia, Hrubý Jeseník Mts, 1182 m, Velká Kotlina glacial cirque, 26 Jun.-25 Jul. 2006, MT, J. Roháček and J. Ševčík leg. (TSPC).

\section{Distribution}

Previously known only from Sweden and Latvia (Gagné \& Jaschhof 2014). New to central Europe including $\mathrm{CZ}$.

\section{Discussion}

Only 44 species of the fungivorous subfamilies have previously been recorded from all of the Czech Republic and Slovakia (Skuhravá \& Košel 1995; Jaschhof 1998, 2015; Mantič et al. 2015; Skuhravá 1997, 2004, 2009; Ševčík 2010; Tóth \& Lukáš 2004). In this paper, a total of 49 species are for the first time reported from the Czech Republic and 33 species from Slovakia. Thirty-nine species are new to the fauna of central Europe. Many of the newly recorded species have only recently been discovered and described from Sweden (see Jaschhof \& Jaschhof 2013). The level of current knowledge of the mycophagous gall midge fauna in the Czech Republic and Slovakia is difficult to estimate, but must certainly be considered as preliminary. Based on species inventories in other well-wooded European countries, such as Germany (Jaschhof 2009) and Sweden (Jaschhof \& Jaschhof 2009, 2013, 2015), we estimate the number of species of the fungivorous subfamilies in the Czech and Slovak Republics at more than 400 , meaning we are at the very beginning with our efforts.

Most of the species found during our survey belong, as far as is known, to a group of boreo-montane and/or silvicolous species, although several localities sampled represent rather thermophilous forests or forest steppes, especially in the Podyjí and Muránska planina national parks. Recent results regarding other families of Bibionomorpha (e.g., Mantič et al. 2015) indicate a distribution pattern in which principally Mediterranean species extend to central Europe, but no such species of Cecidomyiidae were found during this study.

Our inventory of fungivorous Cecidomyiidae in the Czech and Slovak Republics will be continued, with a focus on those localities that in the past proved to be particularly rich in species. Collecting techniques other than Malaise trapping will be tested, including those providing biological information (cf. Ševčík \& Roháček 2008).

Our results add to the pool of data that are necessary for meaningful biogeographical and ecological analyses of these gall midges (cf. Jaschhof \& Jaschhof 2009). Considering that almost all the insect samples interpreted here have been collected in nature reserves and national parks, our data are useful for highlighting the extraordinary natural richness of those areas, and also in supporting decision-making processes in nature conservation in the future.

\section{Acknowledgements}

M.J.'s research is funded by Svenska ArtDatabanken (Swedish Species Information Centre) within the framework of Svenska Artprojektet (Swedish Taxonomy Initiative) (dha 2014-150 4.3). Collecting trips to Slovakia were partly supported by the Ministry of Culture of the Czech Republic by institutional financing of long-term conceptual development of the research institution (the Silesian Museum, MK000100595), internal grants of the Silesian Museum nos IGS201303/2013 and IGS201607/2016. Laboratory facilities and equipment used by the first author were provided by the University of Ostrava (through the institutional support from the Ministry of Education, Youth and Sports of the 
Czech Republic). Miroslav Barták, Jan Ježek and Jindřich Roháček kindly provided their material. We thank Michal Mantič for assembling the photos of localities, Peter J. Chandler for checking the English language, Marcela Skuhravá for reading and commenting on the manuscript prior to submission to the journal, and two anonymous reviewers for their valuable suggestions.

\section{References}

Barták M. \& Kubík Š. 2005. Diptera of Podyji National Park and its Environs. Česká zemědělská univerzita, Praha.

Bílý S. 2015. K významnému životnímu jubileu RNDr. Marcely Skuhravé, CSc. [The important jubilee of RNDr.] Marcela Skuhravá, CSc. Klapalekiana 51: 123-145.

Gagné R.J. \& Jaschhof M. 2014. A Catalog of the Cecidomyiidae (Diptera) of the World. 3rd Edition. Digital version 2. Available from https://www.ars.usda.gov/ARSUserFiles/80420580/Gagne_2014 World_Cecidomyiidae_Catalog_3rd_Edition.pdf [accessed 28 Nov. 2015].

Jaschhof M. 1998. Revision der "Lestremiinae" (Diptera, Cecidomyiidae) der Holarktis. Studia dipterologica Supplement 4: 1-552.

Jaschhof M. 2009. Eine aktualisierte Artenliste der Holzmücken Deutschlands, unter besonderer Berücksichtigung der Fauna Bayerns (Insecta: Diptera: Cecidomyiidae: Lestremiinae). Spixiana 32 (1): 139-151. Available from http://www.pfeil-verlag.de/04biol/pdf/spix32_1 33.pdf [accessed 15 Dec. 2015].

Jaschhof M. 2015. Morphological re-examination reveals that Campylomyza serrata Jaschhof, 1998 is a complex of five cryptic species (Diptera: Cecidomyiidae, Micromyinae). Contributions to Entomology: Beiträge zur Entomologie 65: 373-381.

Jaschhof M. 2016. A review of world Diallactiini (Diptera, Cecidomyiidae, Winnertziinae), with description of six new genera and seventeen new species. Zootaxa 4127 (2): 201-244. https://doi. org/10.11646/zootaxa.4127.2.1

Jaschhof M. \& Jaschhof C. 2009. The wood midges (Diptera: Cecidomyiidae) of Fennoscandia and Denmark. Studia dipterologica Supplement 18: 1-333.

Jaschhof M. \& Jaschhof C. 2013. The Porricondylinae (Diptera: Cecidomyiidae) of Sweden, with notes on extralimital species. Studia dipterologica Supplement 20: 1-392.

Jaschhof M. \& JaschhofC. 2015. New species and new distribution records of Lestremiinae, Micromyinae and Porricondylinae (Diptera: Cecidomyiidae) in Sweden. Zootaxa 3973 (1): 159-174. https://doi. org/10.11646/zootaxa.3973.1.6

Kubík Š. 2001. The species of the family Chloropidae (Diptera) of the Rokytecká, Novohưrecká and Zhưrské peat-bogs in the Šumava Mts (Czech Republic). Acta Universitatis Carolinae Biologica 45: 79-88.

Mantič M., Sikora T., Roháček J. \& Ševčík J. 2015. New and interesting records of Bibionomorpha from the Czech and Slovak Republics. Acta Musei Silesiae, Scientiae Naturales 64: 141-149. https:// doi.org/10.1515/cszma-2015-0020

Roháček J. \& Ševčík J. 2009. Diptera of the Pol'ana Protected Landscape Area - Biosphere Reserve (Central Slovakia). SNC SR, Administration of the PLA-BR Pol'ana, Zvolen.

Ševčík J. 2010. Czech and Slovak Diptera Associated with Fungi. Slezské zemské muzeum, Opava.

Ševčík J. \& Kurina O. 2011. Fungus gnats (Diptera: Sciaroidea) of the Gemer region (central Slovakia): Part 1 - Bolitophilidae, Diadocidiidae, Ditomyiidae and Keroplatidae. Časopis Slezského zemského Muzea Opava (A) 60: 11-23. 
SIKORA T. et al., Fungivorous Cecidomyiidae in the Czech and Slovak Republics

Ševčík J. \& Roháček J. 2008. Fungus gnats (Diptera: Mycetophilidae and Keroplatidae) reared from grass and sedge tussocks in the Czech Republic. Časopis Slezského zemského Muzea Opava (A) 57: $175-178$.

Ševčík J., Kaspřák D., Mantič M., Ševčíková T. \& Tóthová A. 2014. Molecular phylogeny of the fungus gnat family Diadocidiidae and its position within the infraorder Bibionomorpha (Diptera). Zoologica Scripta 43 (4): 370-378. https://doi.org/10.1111/zsc.12059

Ševčík J, Kaspřák D, Mantič M, Fitzgerald S, Ševčíková T, Tóthová A. \& Jaschhof M. 2016. Molecular phylogeny of the megadiverse insect infraorder Bibionomorpha sensu lato (Diptera). PeerJ 4: e2563; https://doi.org/10.7717/peerj.2563

Skuhravá M. 1991. Gallmücken der Slowakei (Cecidomyiidae, Diptera). VI. Die Zoogeographie der Gallmücken. Zborník Slovenského Národného Múzea, Prírodné Vedy 37: 85-178.

Skuhravá M. 1994. The zoogeography of gall midges (Diptera: Cecidomyiidae) of the Czech Republic II. Review of gall midge species including zoogeographical diagnoses. Acta Societatis Zoologicae Bohemicae 58: 79-126.

Skuhravá M. 1997. Faunistic records from the Czech Republic. 67. Diptera: Cecidomyiidae. Klapalekiana 23: 119-120.

Skuhravá M. 2004. Faunistic records from the Czech and Slovak Republics: Diptera. Cecidomyiidae. Dipterologica bohemoslovaca 11: 324-331.

Skuhravá M. 2009. New records and name changes in Cecidomyiidae (Diptera) of the Czech Republic and Slovakia with comments on their occurrence. Folia faunistica Slovaca 14: 131-137. Available from http://www.ffs.sk/pdf/FFS-14-22-Skuhrava-2009.pdf [accessed 20 Dec. 2015].

Skuhravá M. \& Košel V. 1995. Gall midges (Diptera: Cecidomyiidae) from the Western Carpathians caves (Slovakia). Dipterologica Bohemoslovaca 7: 165-174.

Tóth P. \& Lukáš J. 2004. First record of Campylomyza flavipes (Diptera: Cecidomyiidae) from Slovakia. Biologia 59: 282.

Wiegmann B.M., Trautwein M.D., Winkler I.S., Barr N.B., Kim J.W., Lambkin C., Bertone M.A., Cassel B.K., Bayless K.M., Heimberg A.M., Wheeler B.M., Peterson K.J., Pape T., Sinclair B.J., Skevington J.H., Blagoderov V., Caravas J., Kutty S.N., Schmidt-Ott U., Kampmeier G.E., Thompson F.C., Grimaldi D.A., Beckenbach A.T., Courtney G.W., Friedrich M., Meier R. \& Yeates D.K. 2011. Episodic radiations in the fly tree of life. Proceedings of the National Academy of Sciences 108 (14): 5690-5695. https://doi.org/10.1073/pnas.1012675108

Manuscript received: 15 March 2016

Manuscript accepted: 7 July 2016

Published on: 22 March 2017

Topic editor: Gavin Broad

Desk editor: Kristiaan Hoedemakers

Printed versions of all papers are also deposited in the libraries of the institutes that are members of the EJT consortium: Muséum national d'Histoire naturelle, Paris, France; Botanic Garden Meise, Belgium; Royal Museum for Central Africa, Tervuren, Belgium; Natural History Museum, London, United Kingdom; Royal Belgian Institute of Natural Sciences, Brussels, Belgium; Natural History Museum of Denmark, Copenhagen, Denmark; Naturalis Biodiversity Center, Leiden, the Netherlands. 